\title{
A 3-year retrospective review of mortality in women of reproductive age in a tertiary health facility in Port Harcourt, Nigeria
}

This article was published in the following Dove Press journal:

International Journal of Women's Health

16 October 2017

Number of times this article has been viewed

\author{
Ngozi C Orazulike' \\ Justina O Alegbeleye' \\ Christopher C Obiorah ${ }^{2}$ \\ Tamunomie K Nyengidiki' \\ Samuel A Uzoigwe' \\ 'Department of Obstetrics and \\ Gynecology, ${ }^{2}$ Department of \\ Anatomical Pathology, University of \\ Port Harcourt Teaching Hospital, Port \\ Harcourt, Rivers State, Nigeria
}

Purpose: To determine the causes of death and associated risk factors among women of reproductive age (WRA) in a tertiary institution in Port Harcourt, Nigeria.

Patients and methods: This was a retrospective survey of all deaths in women aged 15-49 years at the University of Port Harcourt Teaching Hospital that occurred from January 1, 2013 to December 31, 2015. Data retrieved from ward registers, death registers, and death certificates were analyzed with Epi Info version 7. Comparison of socioeconomic and demographic risk factors for maternal and nonmaternal deaths was done using a multivariate logistic regression model.

Results: There were 340 deaths in the WRA group over the 3 -year period. The majority (155 [45.6\%]) of the women were aged 30-39 years. There were $265(77.9 \%)$ nonmaternal deaths and 75 (22.1\%) maternal deaths. Among the nonmaternal deaths, 124 (46.8\%) had infectious diseases, with human immunodeficiency virus being the most common cause of infection in this group. Breast cancer (13 [4.9\%]), cervical cancer (12 [4.5\%]), and ovarian cancer (11 [4.2\%]) were the most common malignant neoplasms observed. Hypertensive disorders of pregnancy (31 [41.3\%]) and puerperal sepsis (20 [26.7\%]) were the most common causes of maternal deaths. Age and occupation were significantly associated with deaths in WRA $(p<0.05)$. Older women aged $>30$ years (odd ratio $=1.86,95 \% \mathrm{CI}=1.07-3.23$ ) and employed women (odds ratio $=2.55$, $95 \% \mathrm{CI}=1.46-4.45$ ) were more likely to die from nonmaternal than maternal causes.

Conclusion: Most of the deaths were nonmaternal. Infectious diseases, diseases of the circulatory system, and malignant neoplasms were the major causes of death among WRA, with maternal deaths accounting for approximately a quarter. Public health programs educating women on safer sex practices, early screening for cancers, benefits of antenatal care, and skilled attendants at delivery will go a long way to reducing preventable causes of deaths among these women.

Keywords: maternal deaths, nonmaternal deaths, causes of death, infectious diseases

\section{Introduction}

The reproductive age is the prime of a woman's lifespan in terms of fertility and health. Women of reproductive age (WRA) are a vulnerable group usually confronted by the burden of traditional health threats related to infectious diseases and pregnancyrelated conditions, alongside emerging challenges associated with noncommunicable diseases (NCDs). They are the basis for childcare, education, household production, well-being of the family, and care of older people. ${ }^{1}$ In the African context, the degree of subordination of women by men varies by country and geographic or cultural patterns within countries, such that in terms of education, nutrition, and productive labor, men are favored. ${ }^{2}$ The women totally depend on their husbands for economic livelihood,
Correspondence: Ngozi C Orazulike Department of Obstetrics and Gynecology, University of Port Harcourt Teaching Hospital, East-West Road, Choba, Port Harcourt 500102, Rivers State, Nigeria

Tel +2348033048050

Email ngorazulike@yahoo.com (c) (1) (5) 2017 Orazulike et al. This work is published and licensed by Dove Medical Press Limited. The full terms of this license are available at https://www.dovepress.com/terms.php cc. hereby accept the Terms. Non-commercial uses of the work are permitted without any further permission from Dove Medical Press Limited, provided the work is properly attributed. For permission for commercial use of this work, please see paragraphs 4.2 and 5 of our Terms (https://www.dovepress.com/terms.php). 
and critical health decisions of women rest on the shoulders of men. The women are further disadvantaged economically when the traditional responsibilities assigned to them, such as reproduction and being the primary caregiver of the family, do not translate into economic gains. The fact that they are less educated than men has been associated with poor healthseeking behavior, increasing the risk of death.

Maternal deaths are the primary cause of deaths among WRA in sub-Saharan Africa, while NCDs are the major cause of death in resource-rich countries. ${ }^{3,4}$ Irrespective of the epidemiology of the disease, the discrepancy in the mortality index between the two environments is based on supply and demand factors, which affect the health of the population under consideration.

Approximately 287,000 women die due to complications of pregnancy and childbirth annually. ${ }^{5}$ The World Health Organization defines maternal death (mortality) as the death of a woman during pregnancy or within 42 days of termination of pregnancy, irrespective of the duration and site of the pregnancy, from any cause related to or aggravated by the pregnancy or its management, but not from accidental or incidental causes. ${ }^{6}$ Other deaths not related to maternal deaths are termed nonmaternal deaths. Despite calls for more attention to adult female health in resource-poor countries, little change has been seen in terms of availability of reliable data and policy interventions. Here, the risk of adult female death is still considerably high ${ }^{7}$ due to low access to and use of quality health care, low contraceptive prevalence, unskilled attendants, chronic shortages of essential drugs, irregular electricity and water supply, narrow social changes in terms of education, and continuous impoverishment of the female sex.

In order to achieve a reduction in deaths among WRA, global strategies such as those embedded in Millennium Development Goal (MDG) 5 and 6 and Sustainable Development Goal (SDG) 3 were developed by the United Nations. Globally, maternal mortality ratio has declined by $45 \%$ since 1990. New human immunodeficiency virus (HIV) infections reduced by $\sim 40 \%$ between 2000 and 2013 , from an estimated 3.5 million cases to 2.1 million cases. ${ }^{8}$ In Nigeria, a $57 \%$ reduction in maternal mortality ratio from baseline was achieved, as against the $75 \%$ target for MDG 5. Likewise, the target for MDG 6 was not achieved, as Nigeria is still in the second place for the highest burden of HIV/Acquired Immune Deficiency Syndrome (AIDS) worldwide, contributing to $9 \%$ of the global disease burden, with $26 \%$ of women having comprehensive knowledge of the disease. ${ }^{9}$ The SDG 3 with its 13 targets and 26 indicators seems to capture most of the health issues related to WRA. For its monitoring and measurement, regular reliable data on mortality by age, sex, and cause, strengthening of civil registration, and vital statistics systems are needed in all countries. ${ }^{10}$ However, with the previous targets for the MDGs not met in Nigeria, ${ }^{9}$ we are not likely to achieve these new SDG targets. It is against this background that this study reviews the causes of death and any associated risk factors in WRA in Port Harcourt, Nigeria. This would serve as an index of the quality of service rendered by our tertiary institutions, as well as provide information on the relative importance of diseases in WRA.

\section{Patients and methods Study site}

This study was carried out at the University of Port Harcourt Teaching Hospital (UPTH) Nigeria. The UPTH is a 755-bed federal tertiary health facility located in Port Harcourt, Rivers State, which serves both the urban and rural population within the state and the neighboring states. Rivers State has one of the largest oil reserves in the country, a population of about 5.2 million, with a male to female ratio of 1.095 , and an annual growth rate of $3 \% .{ }^{11}$ Port Harcourt, the capital of Rivers State, is a cosmopolitan oil-rich city with people from all parts of the country living in the city. It is made up of 23 local government areas. The Obio-Akpor local government area where the UPTH is located has the largest population of 464,789 inhabitants and a total land mass of $311.71 \mathrm{~km}^{2} .11,12$

\section{Data collection}

This was a record-based retrospective study of all WRA who were managed and died at the UPTH Nigeria, between January 1, 2013 and December 31, 2015. Data from the deaths that occurred in the 3 years were retrieved from the registers of all female wards, including the accident and emergency departments, scrutinized, and recorded in a predesigned pro forma. The different variables obtained were age, marital status, level of education, occupation, date of death, type of death, underlying cause of death, parity, booking status, mode of delivery, and autopsy results. Data were checked for completion and entered into an Excel spreadsheet.

The underlying cause of death is defined as the disease or injury that initiated the pathologic chain resulting in death or the circumstances surrounding the accident or act of violence that caused a lethal injury. Underlying and contributory causes of death were coded according to the International Statistical Classification of Diseases and Related Health Problems, 10th Revision ICD-10. ${ }^{5}$ In our 
study, we only considered the underlying cause of death (not contributory causes of death).

Ethical approval was obtained from the Ethics Committee of the UPTH to conduct this study. In the UPTH, patients or their parents or legal guardians give pretreatment consent in case of a need to review their medical records. Patient data confidentiality was duly maintained in the course of this research.

\section{Statistical analysis}

Information collected from the predesigned pro forma was entered into Epi Info Ver. 7, which was used for data analysis. Differences were considered statistically significant when $p<0.05$ at $95 \%$ CI. Odds ratio (OR) was used to measure association between variables. The results are presented as means with $\mathrm{SD}$, percentages, and tables.

\section{Results}

A total of 340 deaths occurred in the WRA group out of 2,606 adult female admissions over the 3 -year period. The majority (45.6\%) of the women were aged 30-39 years, and 15 (4.4\%) were teenage deaths. More than half (223 [65.5\%]) of the women were married, and 183 (53.8\%) had secondary education, representing about half of the study population. Only a few women $(26$ [7.6\%]) were unemployed. There were 265 (77.9\%) nonmaternal and 75 (22.1\%) maternal deaths (Table 1).

Table 2 shows the leading cause of nonmaternal death as infectious diseases (124 [46.8\%]), followed by diseases of the circulatory system (65 [24.5\%]) and malignant neoplasms (51 [19.3\%]). HIV was the most common infectious disease (61 [23.0\%]). The most common circulatory system disease was cerebrovascular disease (24 [9.1\%]), with diabetes mellitus and chronic liver disease accounting for $16(6 \%)$ and 15 (5.6\%), respectively. Breast cancer (13 [4.9\%]), cervical cancer (12 [4.5\%]), and ovarian cancer (11 [4.2\%]) were the most common malignant neoplasms observed. Hypertensive disorders of pregnancy (31 [41.3\%]) and puerperal sepsis (20 [26.7\%]) were the most common causes of maternal deaths (Table 3). The majority of women (71 [94.7\%]) who died from maternal causes did not have any form of antenatal care. Table 4 shows that age and occupation were significantly associated with deaths in this group of women. It also shows that nonmaternal deaths are significantly higher in women at the peak of their reproductive years (30-39 years).

Table 5 shows that older women of age $>30$ years ( $\mathrm{OR}=1.86,95 \% \mathrm{CI}=1.07-3.23)$ and employed women $(\mathrm{OR}=2.55,95 \% \mathrm{CI}=1.46-4.45)$ were more likely to die from nonmaternal than maternal causes.
Table I Sociodemographic characteristics

\begin{tabular}{|c|c|c|}
\hline Characteristics & $\begin{array}{l}\text { Frequency, } \\
n=340\end{array}$ & Percentage \\
\hline \multicolumn{3}{|l|}{ Age (years) } \\
\hline$\leq 19$ & 15 & 4.4 \\
\hline $20-29$ & 76 & 22.4 \\
\hline $30-39$ & 155 & 45.6 \\
\hline $40-49$ & 94 & 27.6 \\
\hline Mean & $33.9 \pm 8.1$ & \\
\hline \multicolumn{3}{|l|}{ Marital status } \\
\hline Married & 223 & 65.5 \\
\hline Single & 109 & 32.1 \\
\hline Widowed & 4 & 1.2 \\
\hline Divorced & 4 & 1.2 \\
\hline \multicolumn{3}{|c|}{ Educational status } \\
\hline Primary & 28 & 8.2 \\
\hline Secondary & 183 & 53.8 \\
\hline Tertiary & 129 & 38.0 \\
\hline \multicolumn{3}{|l|}{ Parity $(n=75)$} \\
\hline 0 & 29 & 39.0 \\
\hline I & 13 & 17.3 \\
\hline $2-4$ & 14 & 18.7 \\
\hline \multicolumn{3}{|l|}{ Religion } \\
\hline Christianity & 331 & 97.4 \\
\hline Islam & 9 & 2.6 \\
\hline \multicolumn{3}{|l|}{ Occupation } \\
\hline Civil servant & 59 & 17.4 \\
\hline Farming & 16 & 4.7 \\
\hline Housewife & 43 & 12.7 \\
\hline Student & 49 & 14.4 \\
\hline Business & 147 & 43.2 \\
\hline Unemployed & 26 & 7.6 \\
\hline \multicolumn{3}{|l|}{ Deaths } \\
\hline Nonmaternal & 265 & 77.9 \\
\hline Maternal & 75 & 22.1 \\
\hline
\end{tabular}

There were no autopsies done for any of the deaths, as consent was not given for the procedure.

\section{Discussion}

Deaths in WRA have long been a source of concern to health policymakers and health organizations. Various efforts have been made to improve the status of women and to reduce maternal deaths in Nigeria. The efforts include maternal health promotion to increase utilization of family planning, antenatal care and prevention of mother to child transmission of HIV, prevention and management of obstetric complications (eg, safe management of eclampsia and ante/ postpartum hemorrhage, and clinical audit of the quality of obstetric services), and health system strengthening (eg, policy for free Maternal Newborn and Child Health services and electronic health information management). ${ }^{13}$ These interventions were carried out between 1990 and 2014, with a majority of the interventions done after 2000 , as there 
Table 2 Causes of nonmaternal death

\begin{tabular}{|c|c|c|c|}
\hline Characteristics & $\begin{array}{l}\text { Frequency, } \\
n=265\end{array}$ & Percentage & Percentage \\
\hline Infectious diseases & 124 & $f / I 24$ & 46.8 \\
\hline HIV alone & 61 & 49.2 & 23.01 \\
\hline $\mathrm{HIV}+\mathrm{PTB}$ & 43 & 34.7 & 16.23 \\
\hline PTB alone & 4 & 3.2 & 1.51 \\
\hline Viral hepatitis & 4 & 3.2 & 1.51 \\
\hline Meningitis & 3 & 2.4 & 1.13 \\
\hline Septicemia & 3 & 2.4 & 1.13 \\
\hline Appendicitis & 2 & 1.6 & 0.75 \\
\hline Tubo-ovarian abscess & 2 & 1.6 & 0.75 \\
\hline Guillain-Barre syndrome & 2 & 1.6 & 0.75 \\
\hline $\begin{array}{l}\text { Diseases of the } \\
\text { circulatory system }\end{array}$ & 65 & $f / 65$ & 24.5 \\
\hline Cerebrovascular accident & 24 & 36.9 & 9.1 \\
\hline $\begin{array}{l}\text { Diabetes mellitus with } \\
\text { complications }\end{array}$ & 16 & 24.6 & 6.0 \\
\hline Chronic liver disease & 15 & 23.1 & 5.6 \\
\hline $\begin{array}{l}\text { Sickle cell disease with } \\
\text { anemia }\end{array}$ & 5 & 7.7 & 1.9 \\
\hline Congestive cardiac failure & 5 & 7.7 & 1.9 \\
\hline Malignant neoplasms & 51 & $f / 5 I$ & 19.25 \\
\hline Breast cancer & 13 & 25.4 & 4.9 \\
\hline Cervical cancer & 12 & 23.5 & 4.5 \\
\hline Ovarian cancer & II & 21.5 & 4.2 \\
\hline Leukemia & 5 & 9.8 & 1.9 \\
\hline Choriocarcinoma & 3 & 5.9 & 1.1 \\
\hline Endometrial cancer & 2 & 3.9 & 0.8 \\
\hline Leiomyosarcoma & I & 2.0 & 0.4 \\
\hline Hodgkin's lymphoma & I & 2.0 & 0.4 \\
\hline Colorectal cancer & I & 2.0 & 0.4 \\
\hline Soft tissue sarcoma & I & 2.0 & 0.4 \\
\hline Nasopharyngeal tumor & 1 & 2.0 & 0.4 \\
\hline Trauma & 18 & $f / 18$ & 6.8 \\
\hline $\begin{array}{l}\text { Road traffic accident with } \\
\text { head injury }\end{array}$ & 11 & 61.1 & 4.2 \\
\hline Burns & 7 & 38.9 & 2.6 \\
\hline Others & 7 & $f / 7$ & 2.6 \\
\hline End-stage renal disease & 2 & 28.6 & 0.7 \\
\hline $\begin{array}{l}\text { Postoperative } \\
\text { hemorrhage (gynecologic) }\end{array}$ & 2 & 28.6 & 0.7 \\
\hline SOL with hemiparesis & I & 14.3 & 0.4 \\
\hline Motor neuron disease & I & 14.3 & 0.4 \\
\hline Acute severe asthma & I & 14.3 & 0.4 \\
\hline
\end{tabular}

Abbreviations: f, frequency; HIV, human immunodeficiency virus; PTB, pulmonary tuberculosis; SOL, space-occupying lesion.

was increased awareness and commitment by the national government and health authorities after the Millennium declaration. As a result, there was a consistent reduction in national maternal mortality ratio, although it remains significantly high in comparison with other countries of the world..$^{14}$ For these health interventions to be effective, it is important for policymakers and planners to be aware of what causes death among WRA group, be it maternal or nonmaternal. Many developing countries, including Nigeria, with the highest burden of diseases continue to lack routine,
Table 3 Characteristics of maternal death

\begin{tabular}{|c|c|c|}
\hline Causes & $\begin{array}{l}\text { Frequency, } \\
n=75\end{array}$ & Percentage \\
\hline Hypertensive disorders & 31 & 41.3 \\
\hline Puerperal sepsis & 20 & 26.7 \\
\hline Hemorrhage & 15 & 20.0 \\
\hline Obstructed labor & 6 & 8.0 \\
\hline Complication from medical disorders & 2 & 2.7 \\
\hline \multicolumn{3}{|l|}{$\mathrm{DKA}+\mathrm{SCD}$} \\
\hline Anesthetic complication (spinal shock) & I & 1.3 \\
\hline \multicolumn{3}{|l|}{ Mode of delivery } \\
\hline Cesarean section & 38 & 48.0 \\
\hline Vaginal delivery & 27 & 36.0 \\
\hline Exploratory laparotomy & 7 & 9.3 \\
\hline Died undelivered & 5 & 6.7 \\
\hline \multicolumn{3}{|l|}{ Booking status } \\
\hline Unbooked & 71 & 94.7 \\
\hline Booked & 4 & 5.3 \\
\hline
\end{tabular}

Abbreviations: DKA, diabetic ketoacidosis; SCD, sickle cell disease.

representative, and high-quality information on causes of death in WRA. ${ }^{15,16}$

This survey showed that age and occupation were significantly associated with deaths in WRA. Nonmaternal deaths were significantly higher in women in the peak of their reproductive years. This may induce a demographic shift if allowed to continue, as WRA are the basis of repopulation, childcare and education, well-being of the family, and care of the older people. ${ }^{1}$ The death of a woman will impact negatively on the child, as even though the extended family tends to mitigate the impact through their care of orphans, it is not the same as the care of a mother. Furthermore, we discovered that deaths in WRA were significantly higher among those who were employed. These women are an important economic force in any country; thus, their death will impact negatively on the socioeconomic status of the family. It is possible that these women are so busy that they neglect to take the necessary preventive measures in caring for their health and possibly have lifestyle modifications that are detrimental to good health, such as lack of exercise and regular health checkups.

Among the deaths that occurred in WRA in our hospital, $78 \%$ were due to nonmaternal causes, while $22 \%$ were due to maternal causes. This buttresses the fact that equal attention needs to be paid to these nonmaternal deaths plaguing our women. In this survey, the leading cause of nonmaternal death was infectious diseases, with HIV being the most common. In combination with pulmonary tuberculosis complicating HIV (HIV alone and HIV + PTB as shown in Table 2), HIV accounted for $84 \%$ of deaths due to infections. Similar studies performed in Nigeria, South Africa, and India also found HIV/pulmonary tuberculosis to be the leading 
Table 4 Comparison of socioeconomic and demographic risk factors for maternal and nonmaternal deaths

\begin{tabular}{|c|c|c|c|c|c|}
\hline Characteristics & $\begin{array}{l}\text { Maternal death } \\
\text { frequency }(\%)\end{array}$ & $\begin{array}{l}\text { Nonmaternal death } \\
\text { frequency }(\%)\end{array}$ & Total & $\begin{array}{l}\text { Chi-square } \\
\left(\chi^{2}\right)\end{array}$ & p-value \\
\hline \multicolumn{6}{|c|}{ Age group (years) } \\
\hline$\leq 19$ & $\mathrm{I}(\mathrm{I} .3)$ & $14(5.3)$ & $15(4.4)$ & 15.59 & $0.00 I^{*}$ \\
\hline $20-29$ & $22(29.3)$ & $54(20.4)$ & $76(22.4)$ & & \\
\hline $30-39$ & $43(57.3)$ & $112(42.3)$ & $155(45.6)$ & & \\
\hline $40-49$ & $9(12.0)$ & $85(32.1)$ & $94(27.7)$ & & \\
\hline Total & 75 & 265 & 340 & & \\
\hline \multicolumn{6}{|l|}{ Marital status } \\
\hline Married & $52(69.3)$ & |7| (64.5) & $223(65.6)$ & 1.58 & 0.664 \\
\hline Single & $22(29.3)$ & $87(32.8)$ & $109(32.1)$ & & \\
\hline Divorced & $0(0.0)$ & $4(1.5)$ & $4(1.2)$ & & \\
\hline Widowed & $\mathrm{I}(\mathrm{I} .3)$ & $3(1.1)$ & $4(1.2)$ & & \\
\hline Total & 75 & 265 & 340 & & \\
\hline \multicolumn{6}{|l|}{ Occupation } \\
\hline Business & $26(34.7)$ & $|2|(45.7)$ & 147 (43.2) & 21.23 & $0.00 I^{*}$ \\
\hline Civil servant & $7(9.3)$ & $52(19.6)$ & $59(17.4)$ & & \\
\hline Farming & $3(4.0)$ & $13(4.9)$ & $16(4.7)$ & & \\
\hline Housewife & $15(20.0)$ & $28(10.6)$ & $43(12.7)$ & & \\
\hline Student & II (I4.7) & $38(14.3)$ & $49(14.4)$ & & \\
\hline Unemployed & $13(17.3)$ & $13(4.9)$ & $26(7.7)$ & & \\
\hline Total & 75 & 265 & 340 & & \\
\hline
\end{tabular}

Note: *Statistically significant $(p<0.05)$.

nonmaternal cause of death in this age group. ${ }^{16-19}$ However, it is at variance with the findings of another study from Ilesa, Nigeria, where trauma was the predominant cause of death. ${ }^{20}$ This may be because Ilesa is a rural town and HIV testing is higher in urban areas than in rural areas. ${ }^{21}$ The high HIV/ AIDS mortality in this survey may not be surprising because of the low uptake of voluntary counseling and testing despite the test being free, including the introduction of highly active antiretroviral therapy. As such, these women presented late with complications, which may have increased their risk of death. The second most common cause of nonmaternal death was circulatory system disease. Among this group of women, cerebrovascular disease was the most common. This was followed by diabetes mellitus and chronic liver disease. These NCDs are becoming a menace in Nigeria, probably due to the westernization of our diet and lifestyle. A similar result was obtained in the study by Kulkarni et al, which showed heart diseases and cerebrovascular disease as two of the five leading causes of death in both urban and rural areas in this age group. ${ }^{19}$ These were previously thought to be diseases of developed countries and older age groups. Malignant neoplasms constituted $19.3 \%$ of deaths. Cancers of the breast,

Table 5 Comparison of socioeconomic and demographic risk factors for maternal and nonmaternal deaths using logistic regression model

\begin{tabular}{|c|c|c|c|c|c|}
\hline Characteristics & $\begin{array}{l}\text { Nonmaternal death } \\
\text { frequency (\%) }\end{array}$ & $\begin{array}{l}\text { Maternal death } \\
\text { frequency (\%) }\end{array}$ & Total & OR $(95 \% \mathrm{Cl})$ & $p$-value \\
\hline \multicolumn{6}{|c|}{ Age group (years) } \\
\hline$>30$ & 177 & 39 & 216 & 1.86 & $0.03 *$ \\
\hline$\leq 30$ & 88 & 36 & 124 & $(1.07-3.23)$ & \\
\hline Total & 265 & 75 & 340 & & \\
\hline \multicolumn{6}{|l|}{ Marital status } \\
\hline Unmarried & 94 & 23 & 117 & 0.80 & 0.525 \\
\hline Married & $17 \mid$ & 52 & 223 & $(0.45-1.44)$ & \\
\hline Total & 265 & 75 & 340 & & \\
\hline \multicolumn{6}{|l|}{ Occupation } \\
\hline Employed & 186 & 36 & 222 & 2.55 & $0.00 I^{*}$ \\
\hline Unemployed & 79 & 39 & 118 & $(1.46-4.45)$ & \\
\hline Total & 265 & 75 & 340 & & \\
\hline
\end{tabular}

Notes: *Statistically significant $(p<0.05)$. Women who are older $(>30$ years) are 1.86 times more likely to experience nonmaternal death than younger women $(\leq 30$ years) $(\mathrm{OR}=1.86,95 \% \mathrm{Cl}=1.07-3.23 ; p=0.03)$. Also, women who are either employed/self-employed are 2.55 times more likely to experience nonmaternal death than unemployed women $(\mathrm{OR}=2.55,95 \% \mathrm{Cl}=1.46-4.45 ; p=0.00 \mathrm{I})$. There was no statistical significant association between marital status and form of death.

Abbreviation: $O R$, odds ratio. 
cervix, and ovary were the three most common cancers in this review. Studies performed in Ilesa and Lagos, Nigeria also showed similar prevalence of these cancers. ${ }^{20,22}$ These cancers are largely preventable, especially since breast and cervical cancers can be detected in their early stage. Breast cancer screening through mammography, which is used for early detection, is either unavailable or expensive and is often beyond the reach of most people in resource-poor countries such as Nigeria. ${ }^{23}$ In recent times, breast self-examination is being advocated, but may not be used to a large extent as to improve outcome. ${ }^{24}$ Cervical smear, often used for early detection of premalignant cervical lesions, and the highly effective vaccine against human papilloma virus still have very low uptake either due to ignorance, illiteracy, or poverty. ${ }^{1}$ Low-cost visual inspection with acetic acid is being done especially in remote areas for early detection of cervical cancers with good outcomes, as illustrated by findings from India. ${ }^{25}$

Deaths from trauma were less. These trauma deaths were due to road traffic accidents with head injury, while the rest were due to third-degree burns. Although this may not be the exact situation in the general population, many hospital-based data may be reflective of the statistics in the population. ${ }^{26}$

Maternal deaths accounted for barely a quarter of deaths among WRA in this study. Many studies have shown a relatively high maternal mortality rate in Nigeria, ${ }^{14,27,28}$ with the latest National Demographic Health Survey of 2013 of 576 per 100,000 live births showing a $57 \%$ reduction from the baseline, as against the $75 \%$ MDG target. ${ }^{9}$ A more concerted effort is needed in the implementation of already existing policies on reduction of maternal mortality if we are to meet the SDG target of reducing the maternal mortality rate to $<70 / 100,000$ live births by $2030 .{ }^{10}$ This study showed that hypertensive disorders of pregnancy were the most common cause of maternal deaths, which occurred mostly in the third trimester, followed by puerperal sepsis and hemorrhage. This may be attributed to the fact that most of the women had no form of antenatal care and were referred to us with severe pre-eclampsia and eclampsia. This is similar to the reports from previous studies conducted in Nigeria. ${ }^{19,27,29}$ Hypertensive disorders of pregnancy were also the most common cause of death in a similar study done at the same center over a decade ago. ${ }^{30}$ This similarity may be because these are all tertiary hospitals that have facilities for emergency obstetric care, thus serving as referral centers for women with complications, who hitherto had no form of antenatal care. Other studies found puerperal sepsis and hemorrhage as the most common causes of maternal deaths. ${ }^{31-33}$
Overall, $\sim 58 \%$ of deaths in WRA were due to infectious diseases and maternal death. These diseases are largely preventable. While developed countries have implemented strategies to curb their spread, we are grappling with combating them. This simply means awareness for HIV/AIDS needs to be increased by education of the populace, setting up effective interventions against HIV/AIDS, and scaling upward the use of highly active antiretroviral therapy. For maternal deaths, widespread use of antenatal care, skilled attendants at all deliveries, adequate and effective referral systems for high-risk pregnancies, proper management protocols for obstetric emergencies, and greater acceptability of family planning services would go a long way to prevent many deaths among WRA.

The finding that none of the cases reviewed underwent postmortem examination shows the poor acceptability and tolerance of autopsy practice in our environment. Although there is a global decline in the rates of autopsies, the zero tolerance shown in this study is unacceptable as it negates the possible gains of autopsy practice, especially in our resourcepoor country where medical infrastructural limitation and poverty preclude precise clinical diagnosis. Autopsy provides the most veritable approach to determine the cause and mechanism of death. Thus, maternal autopsies provide information that serves as an invaluable tool for the prevention of future maternal deaths, provides robust and holistic guidance for health policy formulation, and is essential for proper death certification. By not having postmortem examinations, the opportunity for incidental findings among the cases was not harnessed, especially as experience has shown that such findings advanced and reshaped medical knowledge and practice. The adoption and implementation of autopsy policy by management will ensure a reversal of the negative trend.

A hospital-based study such as this is often the second best to studies of deaths conducted in communities and, indeed, in the general population, as it is of vital importance to health planners. Unfortunately, in resource-poor countries such as Nigeria, these studies are hardly conducted due to cost and logistics and herein lies the problem. Hospital-based data thus become very useful, especially if monitored over a period of time, as they may assist in assessing changes in disease and death pattern, thus aiding health planners to restrategize.

\section{Conclusion}

Nonmaternal deaths accounted for the majority of deaths seen in WRA in this study. Furthermore, HIV/AIDS was the most common infection plaguing our women. Development of effective low-cost health intervention strategies including 
health education should be a priority for health managers. Implementation of obstetric services essential for life-saving interventions should be key in dealing with WRA, and the importance of an effective national maternal death review should not be underscored. The hospital management should adopt a policy for implementation of autopsies.

\section{Disclosure}

The authors report no conflicts of interest in this work.

\section{References}

1. World Health Organization: Women and health: today's evidence tomorrow's agenda. Geneva: World Health Organization; 2009:1-108.

2. Shayo EH, Norheim OF, Mboera LE, et al. Challenges to fair decisionmaking processes in the context of health care services: a qualitative assessment from Tanzania. Int J Equity Health. 2012;11:30.

3. Lopez AD, Mathers CD. Measuring the global burden of disease and epidemiological transitions: 2002-2030. Ann Trop Med Parasitol. 2006; 100(5-6):481-499.

4. Mathers CD, Boerma T, Ma Fat D. Global and regional causes of death. Br Med Bull. 2009;92:7-32.

5. World Health Organization. Women's health fact sheet. In: WHO editors. WHO Fact Sheet. Geneva: World Health Organization; 2013. Accessed March 9, 2017.

6. World Health Organization. International Statistical Classification of Diseases and Related health problems. 10th revision. 2010 Edition. Geneva: World Health Organization; 2010:156-158.

7. Mane M, Fisker AB, Ravn H, Aaby P, Rodrigues A. Trends and determinants of mortality in women of reproductive age in rural Guinea-Bissau, West Africa - a cohort study. BMC Women's Health. 2013;13:48

8. United Nations Millennium project. Who they are. Available from: http://www.UN milleniumproject.org/goals/. Accessed November 11, 2015. Google scholar.

9. Durokifa AA, Abdul-Wasi BM. Evaluating Nigeria's Achievement of the Millennium Development Goals (MDGs): Determinants, Deliverables, and Shortfalls. Africa's Public Service Delivery \& Performance Review. 2016;4(4):656-683.

10. World Health Organization Publications. World Health Statistics; Chapter 6: SDG Health and Health-related targets, 2016.

11. Rivers State Government [Internet]. Rivers State. Overview; [cited 2017 Mar 3]. Available from: https://riversstate.net.ng/overview/. Accessed March 3, 2017.

12. Kingsley Chinda. A brief history of Obio-Akpor Local Government Area Rivers State; 2013

13. Kana MA, Doctor HV, Peleteiro B, Lunet N, Barros H. Maternal and child health interventions in Nigeria: a systematic review of published studies from 1990 to 2014. BMC Public Health. 2015;15:334.

14. Kassebaum NJ, Bertozzi-Villa A, Coggeshall MS, et al. Global, regional, and national levels and causes of maternal mortality during 1990-2013: a systematic analysis for the Global Burden of Disease study 2013. Lancet. 2014;384(9947):980-1004.

15. Gemechu T, Tinsae M, Ashenafi S, et al. Most common causes of natural and injury-related deaths in Addis Ababa. Pathol Res Pract. 2009;205(9):608-614.

International Journal of Women's Health

\section{Publish your work in this journal}

The International Journal of Women's Health is an international, peerreviewed open-access journal publishing original research, reports, editorials, reviews and commentaries on all aspects of women's healthcare including gynecology, obstetrics, and breast cancer. The manuscript management system is completely online and includes
16. Gulati BK, Kumar A, Pandey A. Cause of death by verbal autopsy among women of reproductive age in Rajasthan, India. Int J Sci Rep. 2015; 1(1):56-60.

17. Mustapha A, Ejembi CL. Causes of death of women in the reproductive age group. Sahel Med J. 2011;14(2):94-99.

18. Nabukalu D, Klipstein-Grobusch K, Herbst K, Newell ML. Mortality in women of reproductive age in rural South Africa. Glob Health Action. 2013;6:22834.

19. Kulkarni R, Chauhan S, Shah B, Menon G. Cause of death among reproductive age group women in Maharashtra, India. Indian J Med Res. 2010;132:150-154.

20. Omoniyi-Esan O, Olaofe O, Onwubuya M, Fadahunsi O, Komolafe A. Pattern of deaths in females in a tertiary health center, South-west, Nigeria. Int J Womens Health. 2011;3:307-312.

21. National Population Commission (NPC) Nigeria and ICF International Nigerian. Nigeria Demographic and Health Survey 2013. Key Findings. Abuja, Nigeria and Rockville, Maryland, USA: NPC and IPF International; 2014.

22. Anorlu RI, Obodo K, Makwe CC. Cancer mortality among patients admitted to gynecological wards at Lagos University Teaching Hospital, Nigeria. Int J Gynecol Obstet. 2010;110(3):268-269.

23. Lawal O, Murphy F, Hogg P, Nightingale J. Mammography screening in Nigeria: a critical comparison to other countries. Radiography. 2015; 21(4):348-351.

24. Shrivastava SR, Shrivastava SP, Ramasamy J. "Self Breast examination: a tool for early diagnosis of breast cancer." Ame J Pub Health Res. 2013;1(6):135-139.

25. Poli UR, Bidinger PD, Gowrishankar S. Visual Inspection with Acetic acid (VIA) screening programme: 7 years experience in early detection of cervical cancer in rural South India. Indian J Community Med. 2015; 40(3):203-207.

26. Adeolu AA, Arowolo OA, Alatise OI, et al. Pattern of death in a Nigerian teaching hospital; 3-decade analysis. Afr Health Sci. 2010; 10(3):266-272.

27. Agan TU, Archibong EI, Ekabua JE, et al. Trends in maternal mortality at the University of Calabar Teaching Hospital, Nigeria, 1999-2009. Int $J$ Womens Health. 2010;2:249-254.

28. Bukar M, Kunmanda V, Moruppa J, Ehalaiye B, Takai U, Ndonya D Maternal mortality at federal medical centre yola, Adamawa state: a five year review. Ann Med Health Sci Res. 2013;3(4):568-571.

29. Yar'zever SI. Temporal analysis of maternal mortality in Kano state, Northern Nigeria: a six-year review. Ame J Public Health Res. 2014;2(2): $62-67$.

30. Uzoigwe SA, John CT. Maternal mortality in the University of Port Harcourt Teaching Hospital, Port Harcourt in the last year before the new millennium. Niger J Med. 2004;13(1):32-35.

31. Mlambo C, Chinamo C, Zingwe T. An investigation of the causes of maternal mortality in Zimbabwe. Med J Soc Sci. 2013;4(14): $615-620$.

32. Ezugwu EC, Agu PU, Nwoke MO, Ezugwu FO. Reducing maternal deaths in a low resource setting in Nigeria. Nig J Clin Pract. 2014;17(1): $62-66$.

33. Pierre-Marie T, Halle-Ekane G, Da Itambi M, Enow MR, Mawamba Y, Fomulu JN. Maternal mortality in Cameroon: a University Teaching Hospital report. Pan Afr Med J. 2015;21:16.

\section{Dovepress}

a very quick and fair peer-review system, which is all easy to use. Visit http://www.dovepress.com/testimonials.php to read real quotes from published authors. 